\title{
THE NEW PRINCIPLES IN INTERNAL AUDIT FUNCTION IN BANKS: STAGNATION OR STEP FORWARD? ${ }^{1}$
}

\author{
Klára Kubáňová ${ }^{2}$ \\ Faculty of Law, Charles University in Prague, Czech Republic \\ email: klara.kubanova@dentons.com
}

KUBÁŇOVÁ, Radka. The new principles in internal audit function in banks: stagnation or step forward? International and Comparative Law Review, 2012, Vol. 12., No. 2, pp. 61-69. DOI: 10.1515/iclr-2016-0086.

\begin{abstract}
Article reflects the recent developments in the field of internal audits within the banks (the document on the internal audit function in banks issued by the Basel Committee on Banking Supervision in 2012). It covers the processes of the internal audits, the relations between supervisors and auditors and the main principles covering the internal audits in banks.
\end{abstract}

Keywords: banks, supervision, internal audit, relations, principles

In June 2012 the Basel Committee on Banking Supervision issued The internal audit function in banks ${ }^{3}$, the revision of Internal audit in banks and the supervisor's relationship with auditors ${ }^{4}$ issued in 2001. The internal audit function in banks should be a reaction to the crisis that has begun in 2007 and should take into consideration the main failure of both individual banks and a system as a whole. As this 2012 document is the reaction to the crisis suffered, the comparison with previous document should demonstrate whether the current principles are stronger and will be more sufficient and whether these can effectively help and prevent the spread of the crisis.

1 This text has been elaborated with financial support and within the project "Financial and legal tools of the struggle with the debt crisis", SVV No. 264 407/2012, realized at the Law Faculty, Charles University in Prague

2 Department of Financial Law and Financial Sciences, Law Faculty of the Charles University in Prague.

3 Basel Committee on Banking Supervision. The internal audit function in banks [online]. 2012 [2012-08-12]. ISBN 92-9197-140-5. Available at: http://www.bis.org/publ/bcbs223.pdf

4 Basel Committee on Banking Supervision. Internal audit in banks and the supervisor's relationship with auditors [online]. 2001 [2012-08-12]. Available at: http://www.bis.org/publ/ bcbs84.pdf 


\section{Internal auditing}

The internal auditing was defined in 1999 by the Board of Directors of the Institute of Internal Auditors as "an independent, objective assurance and consulting activity designed to add value and improve an organization's operations; it helps an organization accomplish its objectives by ringing a systematic, disciplined approach to evaluate and improve the effectiveness of risk management, control, and governance processes. 5 " The internal audit should be then the independent review off all bank's activities that should evaluate all risks, take them into account while assessing the risk profile of the bank and oversee that the remedial actions will be taken if necessary.

\section{Internal audit in banks and the supervisor's relationship with auditors}

Internal audit in banks and the supervisor's relationship with auditors issued in 2001 set forth 20 principles for internal audit function. The internal audit function in banks of 2012 promulgates 20 principles as well; these later issued principles are organized in a different way, they are better linked to each other and the document seems to be more complex. At first no fundamental differences could be drawn, but after a detailed comparison, a particular development and elaboration of the 2012 document can be deduced.

\section{Comparison}

As The internal audit function in banks of 2012 follows on the previous document the character of the main leading principles remains constant. Some principles are restructured, but the ideas are unchanged. The majority of principles could be found in both documents, but the 2012 document provides some new, or at least changed, ones. As Ed Larkin, partner at KPMG, confirms "the document has been significantly restructured and principles reordered, making direct comparison difficult"6.

\section{Responsibility of the board of directors and senior management}

The 2012 document sets forth that "the bank's board of directors has the ultimate responsibility for ensuring that senior management establishes and maintains an adequate, effective and efficient internal control system and, accordingly, the board should support the internal audit function in discharging its duties

5 The institute of Internal Auditors: Definition of Internal Auditing. [online]. 2012 [201208-12]. Available at: https://na.theiia.org/standards-guidance/mandatory-guidance/pages/ definition-of-internal-auditing.aspx

6 KPMG: Australia. Internal audit function in banks: Consultation and regulatory expectations [online]. 2012 [2012-09-29]. Available at: http://www.kpmg.com/AU/en/IssuesAndInsights/ArticlesPublications/Banking-Newsletter/december-2011/Pages/internal-auditfunction-in-banks-consultation-period.aspx 
effectively. "7 This principle was in the very similar wording included in the 2001 document, where this principle was the leading one followed by other duties like that senior management has to perform establishing system for assessing various risks of the bank activities, system for relating risks to the bank's capital level and methods for monitoring compliance with laws and regulations and supervisory and internal policies, while the board of directors had to review at least once a year the internal control system and capital assessment procedure. ${ }^{8}$ As written above some requirements were released in the 2012 document as these activities should be assigned to the audit committee or/and to special audit department, than to senior management. This release and transfer of liability to the body independent (or not directly dependent) of the bank's economic results is, or should be if followed appropriately, clearly much more preferable than if such activities were assigned to senior management solely. The system for relating risks to the bank's capital level is not included in principles only, but also in many global regulatory standards, for example in the current Basel III.

The board of directors should currently review not only the effectiveness and efficiency of the internal control at least once a year but also the performance of the internal audit function. The responsibilities of senior management are set more thoroughly in the 2012 document, but they basically represent principles of 2001 in an advanced version; senior management remains responsible for internal control of all risks faced by the bank, for reporting the board of directors on the scope and performance of the internal control system and senior management is newly responsible for informing the internal audit of new developments, risks and changes, for taking actions on all internal audit findings and recommendations and senor management should also ensure that the head of internal audit has all necessary information.

\section{Key features of the internal audit function: permanence, independence, competence}

Both 2001 and 2012 document require that "each bank should have a permanent internal audit function" " while according to the new principles the responsibility to ensure the permanency lies upon senior management and the board of directors (previous document imposed the duty to take all necessary measures to ensure the permanence of internal audit on senior management only). Both

7 Basel Committee on Banking Supervision. The internal audit function in banks [online]. p. 3, 2012 [2012-08-12]. ISBN 92-9197-140-5. Available at: http://www.bis.org/publ/bcbs223.pdf

8 Basel Committee on Banking Supervision. Internal audit in banks and the supervisor's relationship with auditors [online]. p. 2, 2001 [2012-08-12]. Available at: http://www.bis.org/ publ/bcbs84.pdf

9 Basel Committee on Banking Supervision. The internal audit function in banks [online]. p. 10, 2012 [2012-08-12]. ISBN 92-9197-140-5. Available at: http://www.bis.org/publ/ bcbs223.pdf 
documents expect the internal audit to be conducted by bank's own internal audit staff.

As permanency, both documents require that the bank's internal audit function must be independent of the audited activities, it should have a sufficient standing and must act with objectivity. The 2001 document stated that "the internal audit department operates under the direct control of either the bank's chief executive officer or the board of directors or its audit committee (if one exists)"10; the new principles issued in 2012 already request the audit committee, or its equivalent, to exist and set forth its authority in the Annex 2 in Responsibilities of a bank's audit committee ${ }^{11}$. The internal audit must be independent in the sense that it must be free to report its findings and assessments, and should not be involved in control measures in any way. Both documents proclaim to be useful to periodically rotate internal audit staff within the internal audit function, which should ensure objectivity and impartiality. While the 2001 document required that internally recruited auditors should not audit activities or functions they performed within the last twelve months, the revised 2012 document does not require any time period for rotation of internal audit staff, but on the other hand the rotation procedure is required to be governed and conducted in accordance with written policy. The call for more independence and autonomy of internal audit function in revised document is also apparent from provision regarding remuneration of the internal audit; the remuneration obviously should not be linked to the financial performance of the bank as a whole and on the opposite it should be determined in accordance with the bank's remuneration policies and practices. To summarize, independence of internal audit function is substantially enhanced in the 2012 document.

Both documents also highlight professional competence and due professional care being essential for the proper functioning of the bank's internal audit function. Section concerning this requirement enumerates skills that internal auditor must have capacity to collect and understand information, examine and evaluate audit evidence and to communicate with the parties interested in internal audit; this should be combined with suitable methodologies, tools and sufficient knowledge; senior internal auditors should be able to draw impacts and supervise the auditors who have only limited competence and skills. These skills should be monitored by the head of internal audit department. Skills required by the 2012 document are still very general; it is on legislative body of every state to transfer them (if this was not done yet) into a binding legal document that can only directly impose these duties on such auditors and management. The appro-

10 Basel Committee on Banking Supervision. Internal audit in banks and the supervisor's relationship with auditors [online]. p. 4, 2001 [2012-08-12]. Available at: http://www.bis.org/ publ/bcbs84.pdf

11 Basel Committee on Banking Supervision. The internal audit function in banks [online]. p. 21, 2012 [2012-08-12]. ISBN 92-9197-140-5. Available at: http://www.bis.org/publ/ bcbs223.pdf 
priate sanctions, applicable to individual auditors or to the bank as a whole, for non-compliance with such provisions should be developed and included into statutory provisions as well.

\section{The internal audit plan}

Both documents also highlight the role of the audit plan which should set down the objectives, tasks and procedure of internal auditing, while the board's approval implies that an appropriate budget will be available to support the internal audit function's activities and simultaneously that the audit plan is flexible according to the risk profile. The audit plan should be annually established by the head of the internal audit function and approved by the board of directors. The 2012 document requires that "the plan should be based on a robust risk assessment (including input from senior management and the board) and should be updated at least annually (or more frequently to enable an ongoing real-time assessment of where significant risks lie)."12 The audit plan is reviewed and approved by the audit committee and it should be also communicated with senior management. The internal audit plan should cover the procedure of auditing, measures necessary to be taken in certain year period and it would be probably useful to include some "crisis scenario" if necessary.

\section{The internal audit charter}

"Each bank should have an internal audit charter that articulates the purpose, standing and authority of the internal audit function within the bank ${ }^{13}$ " defines Principle 5 of the 2012 as well as Principle 6 of 2001 document. The internal audit charter should be, according to the revised document, drawn up and reviewed by the head of internal audit and approved by the board of directors; the previous document also required the approval of senior management; board of directors' approval could have been replaced by audit committee (if existed) - this is not possible any longer. The revised document also provides list of requirements the charter should establish, the only new requirement seems to be the criteria for outsourcing.

In both documents it is included that charter should establish the purpose of internal audit, its position within the bank, the responsibility of the head of internal audit department, the obligation to communicate, or the criteria for providing consulting or advisory services. No fundamental changes between both documents regarding internal audit charter could be found.

12 Basel Committee on Banking Supervision. The internal audit function in banks [online]. p. 10, 2012 [2012-08-12]. ISBN 92-9197-140-5. Available at: http://www.bis.org/publ/ bcbs223.pdf

13 Basel Committee on Banking Supervision. Internal audit in banks and the supervisor's relationship with auditors [online]. p. 5, 2001 [cit. 2012-08-12]. Available at: http://www.bis. org/publ/bcbs84.pdf 


\section{Audit Committee}

Both 2001 and 2012 document emphasize the role of the audit committee within the internal audit function. The audit committee is composed of board of directors. The 2001 document imposed certain responsibilities upon audit committee, but also allowed the situation that such committee had not existed; the revised document on the other side assumes that "large and internationally active banks have an audit committee or its equivalent and that other banks are strongly encouraged to establish such a committee." ${ }^{\prime 4}$ The committee should provide the oversight of the bank's internal auditors; the responsibilities, which have been expanded compared to the 2001 document, are given in the Annex $2{ }^{15}$ of revised document. According to this Annex the audit committee has the responsibility (for example) to monitor the financial reporting, oversee accounting policies and bank's financial statements, ensure that senior management establishes an effective control system and if necessary takes corrective actions, to approve the audit plan, audit charter and code of ethics, review the audit reports, approve or recommend the external auditor, or to address control weaknesses.

The role of audit committee is strengthened; its responsibilities have not been as much expanded than better organized and elaborated in detail. On the other side there are no criteria for membership in the audit committee as it was in 2001 document ${ }^{16}$, the only criteria is, as written above, that the audit committee is a specialized committee within a board of directors.

\section{The relationship of the supervisory authority with the internal audit func- tion}

The relationship between supervisory authority and internal auditors is the one that has been expanded the most. The principles of 2001 defined this relationship pretty briefly and no direct principles or particular requirements

14 Basel Committee on Banking Supervision. The internal audit function in banks [online]. p. 2, 2012 [2012-08-12]. ISBN 92-9197-140-5. Available at: http://www.bis.org/publ/bcbs223. pdf

15 Basel Committee on Banking Supervision. The internal audit function in banks [online]. p. 21, 2012 [2012-08-12]. ISBN 92-9197-140-5. Available at: http://www.bis.org/publ/ bcbs223.pdf

16 The 2001 document stated that „, an audit committee should include at least three members of the board of directors who are not current or former members of senior management. Where members of management are permitted on the audit committee by local law or regulation, they should not constitute a majority of the members of the committee. The members should have a background that is compatible with committee duties. At least one member should have a background in financial reporting, accounting or auditing. For efficiency, the following persons may be allowed to attend regularly the meetings of the audit committee: the chie executive officer or a member of senior management, the head of the internal audit department and the external auditor." Basel Committee on Banking Supervision. Internal audit in banks and the supervisor's relationship with auditors [online]. p. 16, 2001 [2012-08-12]. Available at: http://www.bis.org/publ/bcbs84.pdf 
derived from this document; the 2001 document provided just some basic requirements on supervisory activities like that supervisory authority should periodically review and evaluate the bank's capital adequacy, as well as evaluate the work of internal audit department; supervisory authority should also discuss the risk areas and take appropriate measures. The 2001 document also set forth that supervisors should encourage the discussion between internal and external auditors; there should be a periodic meeting of supervisors, internal and external auditors, where the efficiency of their cooperation should be mainly discussed.

As the relationship between supervisory authority and internal auditing has not been described in detail in 2001 document, the revised one provides much more complex definition. It is set forth that there must be an effective communication between supervisors and internal auditors; this communication must be a basis for supervisors' understanding of the internal audit's role within the particular bank but such communication cannot undermine the independence of both interested parties - their relationship should be transparent. The main tasks of supervisory activities are included in Principle 16 that provides that supervisors should "discuss the risk areas identified by both parties, understand the risk mitigation measures taken by the bank, and monitor the bank's response to weaknesses identified"17. The revised document also lays down a crucial principle that the relationship between supervisory authority and internal audit is two-way; this means that not only internal auditor but also supervisors should share relevant information, which gives both parties an equal standing. The 2012 document also specifies particular matters that should be always covered during the process of supervision: "bank's capital and liquidity positions, its processes and methods for determining, monitoring, controlling and reporting on material risks" ${ }^{\prime 18}$. The document also specifies the information, data, measures taken, various controlling mechanisms and other particular activities that should be reported to supervisors from internal auditors. Based on evaluation of all relevant information and data, the supervisory authority should assess the quality and functioning of the internal audit function, which influences the overall assessment of the bank's risk profile. According to the revised document "supervisors should formally report all weaknesses they identify in the internal audit function to the board of directors and require remedial actions." ${ }^{19}$ By such reporting and actions taken the supervisory authority can improve the function of the internal audit; supervisors may require changes and particular measures

17 Basel Committee on Banking Supervision. The internal audit function in banks [online]. p. 15, 2012 [2012-08-12]. ISBN 92-9197-140-5. Available at: http://www.bis.org/publ/ bcbs223.pdf

18 Basel Committee on Banking Supervision. The internal audit function in banks [online]. p. 16, 2012 [2012-08-12]. ISBN 92-9197-140-5. Available at: http://www.bis.org/publ/ bcbs223.pdf

19 Basel Committee on Banking Supervision. The internal audit function in banks [online]. p. 3, 2012 [2012-08-12]. ISBN 92-9197-140-5. Available at: http://www.bis.org/publ/bcbs223. pdf 
to be included in remediation plan made by board of directors. Although the document mentions the remedy or remediation plan pretty often, no specific remedy is provided. The supervisory authority is given pretty big power and has big influence on internal auditing, but the lack of direct remedial competences weakens such power and this creates barrier in efficiency and effectiveness of the supervisors.

\section{Conclusion:}

The revised document seems to provide more elaborated system for internal audit function; it lays down more requirements that should improve the current internal audit's situation and supervision of bank activities. The revised document requires more independence, provides more competence to internal auditors and strengthens the relationship between internal auditors and the supervisory authority. However, this regulation still seems to be not sufficient.

Under the 2001 document, which is not very different from the revised one, the world suffered one of the biggest crises in its history which has not said the final word yet. It is clear that these principles were not functioning and unfortunately, as the 2012 document brings just "cosmetic changes", it cannot be expected to be effective either. Having regard to the fact that "an internal audit function, independent from management and composed of competent auditors, is a key component of a bank's sound governance framework"20 stated by Stefan Ingves, chairman of the Basel Committee and governor of Sweden's central bank, this document still seems to be too general as it does not provide any specific details and more importantly the document does not take into account the possibility that the internal audit will not follow the imposed rules. It is necessary to realize, even the principles set forth the opposite, that the internal audit is always bias; the internal audit is always dependent on banks results as every individual auditor is the employee of particular bank - in 2006 the internal auditors of Goldman Sachs must have known about the speculating in the Greek debt market; in 2008 the internal audit consciously did not prevent risk transactions with derivatives within the Lehman brothers.

One of the possibilities to improve the stated situation could be the outsourcing of internal audit as the internal audit could never be fully independent. The internal audit function, if outsourced, could be then more powerful guarantee that the bank's activities follow desired requirements. And, as the outsourcing of the internal audit would be on a contractual basis, the particular sanctions could derive from the breach of such contract.

20 Investment Executive. From the Regulators [online]. [2012-09-23]. Available at: http:// www.investmentexecutive.com/-/basel-calls-for-stronger-internal-audit-strategies-forbanks 
The further weakness of the revised principles is that the document does not impose any sanctions if any of the principle is breached and thereby its power is very limited. But the issue lies in the kind of sanction itself; the sanction should not be the nature of any financial punishment; the austerity measures taken in Greece today are the best example of inefficiency of such kind of sanction. And the proof that the solution is not clear and easy one is also the current situation where world's leading economists cannot find the definite answer.

The revised document is probably not the final one. There should be a clearer and more definite document, which imposes direct obligations and sanction if such obligations are breached. The current reaction to the crisis suffered seems to be unfortunately insufficient. 